\title{
局所皮膚冷却による，血液透析穿刺痛の軽減効果
}

\author{
大門 正一郎 ${ }^{1}$ 瀬 戸 利 子 $^{1}$ 保志場 紀子 $^{1}$ 武 市 道 代 $^{1}$ \\ 松山美紀 ${ }^{1}$ 澤崎 真由美 ${ }^{1}$ 上田 律子' ${ }^{1}$ 中 嶋 桂 ${ }^{1}$ \\ 段 一 志 ${ }^{1}$ 藤 井 博 ${ }^{2}$ 川野 充 弘 $^{2}$

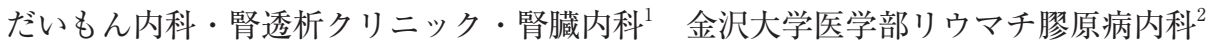

キーワード：皮膚冷却，リドカイン貼付，血液透析，穿刺

〈要旨〉

内シャント穿刺に伴う疼痛は, 血液透析を施行する上で, 頻繁に認められる問題である. われわれは, 11 名の血 液透析患者で, 内シャント穿刺に伴う疼痛を, 穿刺局所を 20 度に冷却した場合 (cool down：CD), リドカイン貼 付を使用した場合 (lidocaine patch：LP), 何もしなかった場合 (control：C) で比較した. 各々の血液透析患者で, CD, LP, C による血液透析を 3 回ずつ施行した. 穿刺時の疼痛は, 疼痛スコア (0 : lack of pain, 10: unbearable pain）を使用し, 各々の患者で, CD, LP, C それぞれの 3 回の穿刺時痛を合計して比較した. 穿刺局所の温度は,

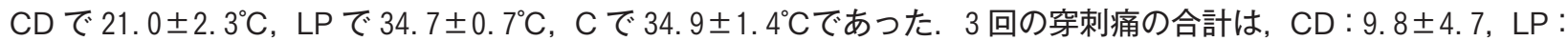

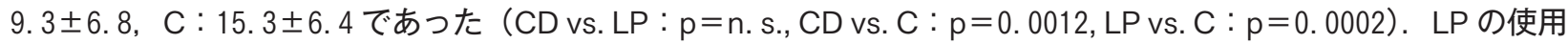
では, 局所の発赤, 瘙痒が時折みられたが, CD では, 副作用はみられなかった. 穿刺局所の冷却は, 血液透析患者 の内シャント穿刺時の痛み軽減に有効な方法と考えられた.

\section{Effect of local cooling of the skin to control pain during arteriovenous fistula cannulation in hemodialysis patients}

Shoichiro Daimon', Toshiko Seto', Noriko Hoshiba', Michiyo Takeichi', Miki Matsuyama', Mayumi Sawasaki', Ritsuko Ueda', Keiko Nakashima', Kazushi Dan', Hiroshi Fujii' and Mitsuhiro Kawano ${ }^{2}$

Department of Nephrology, Daimon Clinic for Internal Medicine, Nephrology and Dialysis ${ }^{1}$; Department of Rheumatology and Collagen Diseases, Kanazawa University ${ }^{2}$

Key words : skin cooling, lidocaine patch (LP), hemodialysis, centesis

〈Abstract〉

Pain during intravenous cannulation is a common problem associated with the hemodialysis procedure. In 11 hemodialysis patients, we compared the pain of arteriovenous fistula cannulation with a cooling the local skin temperature to $20^{\circ} \mathrm{C}$ (CD), that with dermal lidocaine patch (LP) and that without either a patch or cooling down the local skin (C). In every patient, three hemodialysis sessions were performed with CD, LP and $C$ respectively. Degree of pain was expressed by pain scale ( 0 : lack of pain, $10:$ unbearable pain). In each patient the scores of three cannulations utilizing each method were added and compared. Local skin temperatures at the cannulation site were $21.0 \pm 2.3^{\circ} \mathrm{C}$ in $\mathrm{CD}, 34.7 \pm 0.7^{\circ} \mathrm{C}$ in $\mathrm{LP}$ and $34.9 \pm 1.4^{\circ} \mathrm{C}$ in $\mathrm{C}$, respectively. Sum of pain scores was $9.8 \pm$ 4. 7 in CD, $9.3 \pm 6.8$ in LP and 15.3 46.4 in C (CD vs. LP : $p=$ n. s., CD vs. $C: p=0.0012$, LP vs. $C: p=0.0002$ ). In contrast to an occasional rash associated with the use of dermal LP, CD was performed without any complication. $\mathrm{CD}$ is an effective option to reduce the pain associated with intravenous cannulation in hemodialysis procedure.

大門 正一郎 だいもん内科・腎透析クリニック・腎臟内科

干 921-8802 石川県石川郡野々市町押野 1-400

Shoichiro Daimon Tel : 076-294-0066 Fax : 076-294-2330

〔受付日：2009 年 11 月 13 日, 受理日：2010 年 1 月 3 日〕 


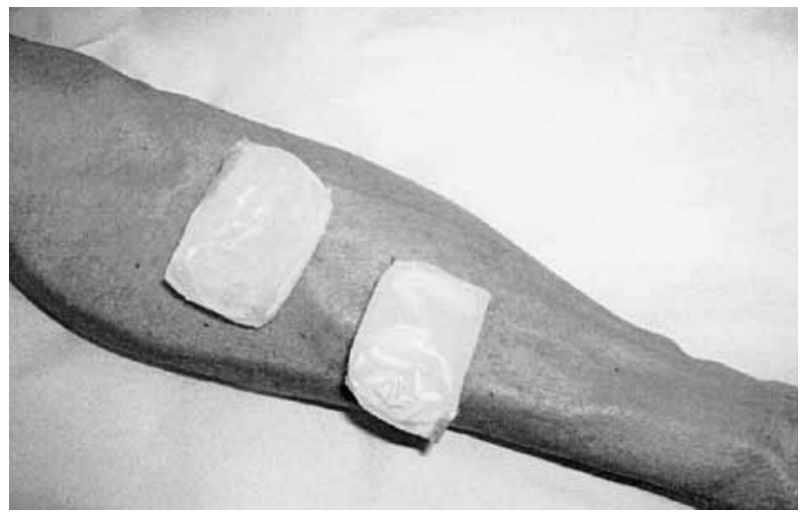

図 1 Cooling jelly

\section{緒言}

慢性腎不全患者の治療法として，腎移植の普及が試 みられているが, 透析を余儀なくされている患者数は, 年々増加し続けている ${ }^{1)}$. 血液透析治療時の血流確保 の方法として, 内シャント，人工血管，カテーテルの 3つの方法があるが，感染症が比較的少なく，患者生 存率も良いとされる内シャントが最良の方法とされて いる ${ }^{2)}$. しかし，内シャントによる血液透析は，毎回， 内シャントの穿刺を必要とし, 穿刺時の疼痛は, 患者 にとっては大きな苦痛である，毎回，同じ場所を穿刺 するボタンホール穿刺は, 容易で疼痛の少ない穿刺法 として発案されたが ${ }^{35)}$, 依然, 穿刺時痛はあり, この 方法は, 穿刺に熟練を要する.

穿刺局所をリドカイン貼付してから穿刺する方法 は, 穿刺痛の軽減に有効と報告され ${ }^{6,7)}$, わが国では広 く使用されているが, リドカイン貼付による局所の発 赤, 瘙痒が, 副作用としてよく認められる。

1951 年, Hardy ら $^{8)}$ は, 皮膚温度が低下するに従い, 疼痛の域值が上昇することを報告した。今回，われわ れは，血液透析患者の内シャント穿刺時の痛みを，穿 刺局所を 20 度に冷却した場合 (cool down：CD), リ ドカイン貼付を使用した場合 (lidocaine patch : LP), 何もしなかった場合 (control：C) で比較検討した.

\section{I．対象と方法}

経過は安定しているが, 内シャント穿刺痛を訴える, 当院通院中の 11 名の血液透析患者を対象とした（男 性 10 名, 女性 1 名, 平均年齢 $63.2 \pm 11.6$ 歳 (42 83), 平均透析期間 $29.1 \pm 20.2(3 \sim 62)$ 少月). 各々の患者 に対し，CD，LP，Cによる血液透析を 3 セッションず つ行った，CDでは，穿刺局所の冷却には，冷凍庫で
冷却されたナイロンに包まれたジェルを使用し，穿刺 局所を 5 から 10 分冷却し（図 1), サーモメーターで, 穿刺局所が 20 度近傍になったのを確認した直後に穿 刺した. LPでは, リドカイン貼付は穿刺の 1 時間以 上前に行い，穿刺直前に外した.

各穿刺には, $16 \mathrm{G}$ 穿刺針 (happy cath, Medikit Corporation. Tokyo, Japan）を使用し，穿刺は，同じ部 位を同じ術者により行われた。穿刺痛は，疼痛スコア (0: lack of pain, 10 : unbearable pain) で表した. CD, LP, C 各々で, 3 回ずつの疼痛スコアを合計して, 各 患者の CD, LP, Cの穿刺痛として比較した.

結果は平均值土標準偏差で表し, $p<0.05$ を有意差 ありと判定した.

\section{II. 結 果}

CD，LP，Cでの穿刺時の皮膚温を表 1 に示す。CD では，皮膚温は $21.0 \pm 2.3^{\circ} \mathrm{C}$ に低下していた。各々の 患者での, CD, LP, Cの 3 回ずつの疼痛スコアの合計 を図 2 に示す。いずれの患者でも，同一の方法での 3 回の疼痛スコアに大きなばらつきは認められず，同程 度の疼痛を訴えた，CD，LPでは，Cに比し，有意に 疼痛スコアの低下がみられた (CD vs. LP : p =n. s., CD vs. $\mathrm{C}: \mathrm{p}=0.0012$, LP vs. $\mathrm{C}: \mathrm{p}=0.0002$ ）（図 3).

\section{III. 考察}

末期腎不全の治療方法としては，血液透析，腹膜透 析，腎移植の 3 つの選択肢がある．末期腎不全患者は 毎年増加しているが，日本では，腎移植は近年増加傾 向とはいえ, 依然少数であり, 維持透析患者は増加し 続けている.

血液透析時の血流確保の方法として, 内シャントは, 人工血管, カテーテルに比し, 感染, 死亡リスクが低 く, 最も優れた方法とされているが2), 内シャントは, 毎治療時に穿刺を必要とし, 穿刺時の疼痛は, 患者, 治療者にとって, 非常にストレスのかかる問題である.

ボタンホール穿刺は，穿刺痛の軽減，容易な穿刺を 目的に考案され，一定の効果はあるが ${ }^{3 \sim 5)}$, 穿刺に熟練 を要し, 穿刺部に静脈瘤を起こす可能性もある.リド カイン貼付による穿刺も穿刺痛軽減に効果的で ${ }^{6,7)}$, わ が国では広く使用されているが貼付部位の発赤, 瘙痒 がしばしば認められる。

1951 年, Hardy $ら^{8)}$ は，皮膚温が低下すると，痛み に対する閾值が上昇すると報告した。 今回，われわれ は, 皮膚を冷却することで穿刺痛の軽減効果があるか, 
表 1 Skin temperature just before the cannulations

\begin{tabular}{lccc}
\hline & $\mathrm{CD}$ & $\mathrm{LP}$ & $\mathrm{C}$ \\
\hline mean $\pm \mathrm{SD}\left({ }^{\circ} \mathrm{C}\right)$ & $21.0 \pm 2.3$ & $34.7 \pm 0.7$ & $34.9 \pm 1.4$ \\
range & $17.0-26.0$ & $33.3-36.0$ & $29.0-36.2$ \\
median & 20.0 & 34.6 & 35.3 \\
\hline
\end{tabular}

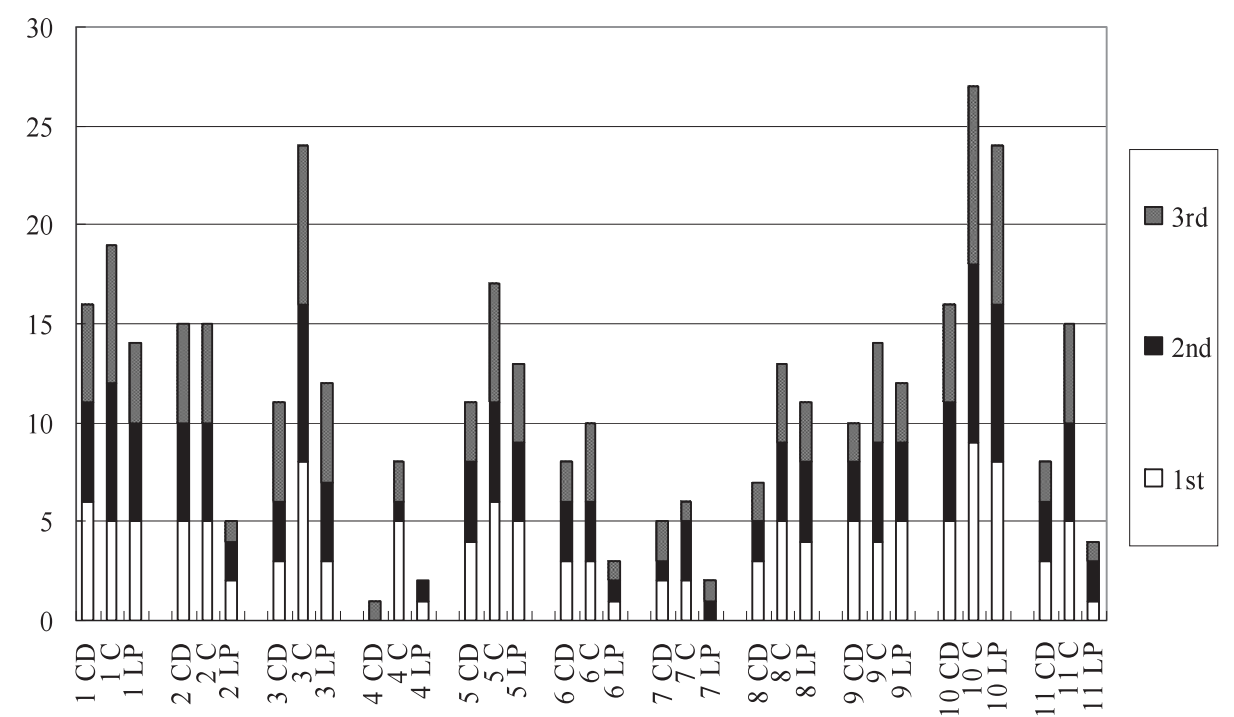

図 2 Sum of pain scores

$\mathrm{CD}=$ cooling down $; \mathrm{LP}=$ lidocaine patch $; \mathrm{C}=$ control (without patch or cooling down the local skin)

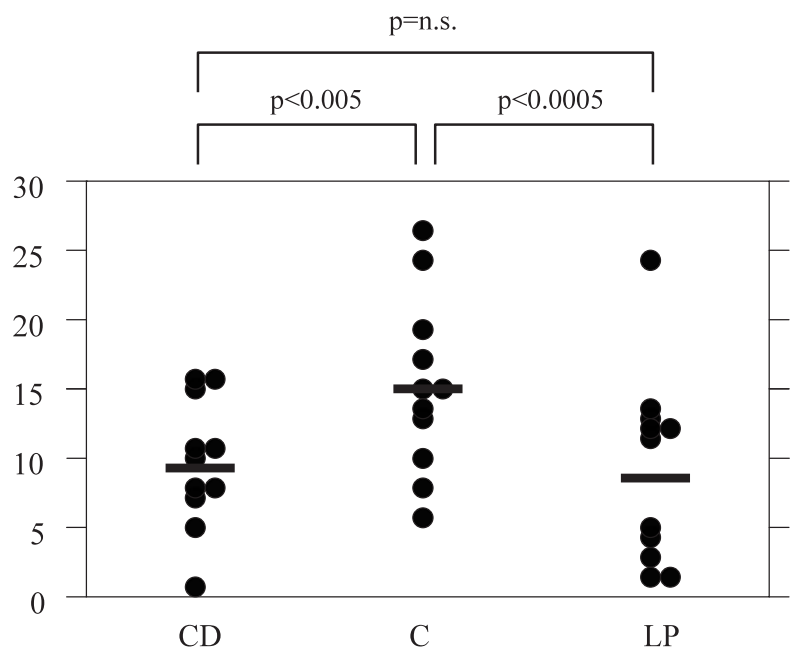

図 3 Sum of pain scores

$\mathrm{CD}=$ cooling down $\mathrm{LP}=$ lidocaine patch $\mathrm{C}=$ control (without patch or cooling down the local skin). () ; sum of pain scores of three cannulations in each patient, $(\boldsymbol{C})$; average of sum of pain scores.

血液透析患者の内シャント穿刺で検討した。皮膚を 15 度以下に冷却すると冷感だけでなく, 痛みの感覚も 出現するとの報告があり ${ }^{9)}, \mathrm{CD}$ での穿刺部の皮膚温を 20 度にした。 ナイロンに包まれたジェルは, 通常の保 冷剤と異なり冷凍しても硬くならないように工夫され
ており (特許出願中), 穿刺部位に 5 から 10 分置くこ とで, 穿刺部位の皮膚温は $21.0 \pm 2.3$ 度に低下したが, 一定時間以上置くことで皮膚温が低下しすぎないよう な工夫が, 今後必要と考えられる。 また, 今回, ジェ ルを取り除いた直後に穿刺したので，穿刺時には穿刺 局所の皮膚温は 20 度から大きく上昇していないと考 えられるが，ジェルを取り除いてから直後に穿刺する ことを日常の穿刺作業のなかで繰り返すことはやや困 難であり, この点にも工夫の余地があると考えられた。

$\mathrm{CD}$ では，疼痛スコアは，冷却しない場合より有意 に低下し，リドカイン貼付後の穿刺と同程度まで低下 した. CDでは,リドカイン貼付で時折みられる局所 の発赤, 瘙痒も認められなかった.

\section{結語}

血液透析患者の内シャント穿刺において，穿刺局所 を 20 度前後に冷却することで, リドカイン貼付と同 程度の穿刺痛軽減効果を期待でき, 副作用もなく, 有 効な方法と考えられた。

謝辞：Creative Medical Engineering Co.（石川県金沢 市）の協力に深く感謝します. 


\section{文献}

1) Lysaght MJ : Maintenance dialysis population dynamics : current trends and long-term implications. J Am Soc Nephrol 13: S37-40, 2002

2) Pastan S, Soucie JM, McClellan WM : Vascular access and increased risk of death among hemodialysis patients. Kidney Int $62:$ 620-626, 2002

3) Twardowski $Z$, Kubara $H$ : Different sites versus constant sites of needle insertion into arteriovenous fistula for treatment by repeated dialysis. Dial Transplant $8:$ 978-980, 1979

4) Toma S, Shinzato T, Fukui H, Nakai S, Miwa M, Takai I, Maeda K : A timesaving method to create a fixed puncture route for the buttonhole technique. Nephrol Dial Transplant 18 : 2118-2121, 2003

5) Verhallen AM, Kooistra MP, van Jaarsveld BC:
Cannulation in hemodialysis : rope-ladder or buttonhole technique? Nephrol Dial Transplant 22 : 26012604, 2007

6) Kitamoto $Y$, Kano $T$, Mishima M, Matsushita $K$, Yasumoto N, Nakano M, Morioka T, Sato T : Dermal patch anesthesia : pain-free puncture of blood access in hemodialysis patients. Am J Kidney Dis 20 : 489491, 1992

7) Hallén B, Olsson GL, Uppfeldt A : Pain-free venopuncture. Effect of application of local anaesthetic cream. Anaesthesia 39 : 969-972, 1984

8) Hardy JD, Goodell H, Wolff GH : The influence of skin temperature upon the pain threshold as evoked by thermal radiation. Science $114:$ 149-150, 1951

9) Tominaga M, Caterina MJ : Thermosensation and pain. J Neurobiol 61 : 3-12, 2004 